\title{
Spatial pattern of structural ageing in eastern Croatia: evolution and explanations
}

\author{
By MARIJAN JUKIC ${ }^{1} \mathcal{E}$ HAFIZ T. A. KHAN ${ }^{2}$
}

\begin{abstract}
This article aims to examine the ageing situation and social policy issues in the Osijek-Baranja County of eastern Croatia. Using historical evidence from census data, research suggests that the evolution of the ageing pattern has been mainly determined by such factors as development of the transport system, changes in political-territorial organisation, supply of jobs in the cities, deagrarianisation and a domestic war in the 1990s. The increased importance of urban centres, through planned industrialisation and administrative centralisation, has accelerated and intensified rural-tourban migration. Consequently, the spatial pattern of structural ageing has been substantially affected. A significant variation was found in urban and rural areas and also within sub-regional units. The findings suggest that the evolution of spatial disparities in the ageing pattern is because of unplanned migration; spatial differences in the level of socio-economic development; the influence of tradition, such as higher fertility rates historically in some
\end{abstract}

\footnotetext{
${ }^{1}$ Marijan Jukic, School of Demography, Australian National University, Canberra, Australia and Institute of Social Sciences Ivo Pilar, Zagreb, Croatia

${ }^{2}$ Hafiz T. A. Khan, Department of Criminology and Sociology, Middlesex University London, London, UK and The Oxford Institute of Population Ageing, The University of Oxford, Oxford, UK
} 
International Journal of Ageing and Later Life

areas; and suburbanisation, notably around the city of Osijek. The article concludes that ageing is affecting the country's economic growth and the formal and informal social support systems, including the provision of resources for older citizens in the endangered areas.

Keywords: ageing, Croatia, spatial pattern, demographic transition, Osijek-Baranja County.

\section{Introduction}

Croatia has recently been ranked as one of the most rapidly ageing countries in the world after Japan and Italy (Bloomberg 2014). It is now among the top ten oldest nations in the world. with about $24.8 \%$ of the population over the age of 60 years. This gives an important message to policy makers to include ageing agenda in national planning and development strategies (UN 2013). Studies show that population ageing is obvious, and it has a profound effect on every aspect of socio-economic development (Khan 2014; McDaniel \& Zimmer 2013; UNFPA 2012). Ageing has not received much attention in the population research discourse in Croatia and yet it has intensified during the second half of the 20th century. This has caused overwhelming economic, social and developmental problems, as well as growing disparities between the regions (Jukic \& Turk 2010). Research in the past has focused either on the determinants of population dynamics at the national level (WertheimerBaletic 2004) or at the regional level (Jukic \& Andrakovic 2009; Jukic \& Turk 2010). But these studies suffered from insufficient empirical evidence and by the lack of adequate recognition of its consequences. Little is known about the dynamics of ageing by time and space, particularly with regards to the spatial distribution of ageing populations at sub-regional levels in Croatia.

Unlike previous research, this article is unique in employing a comprehensive approach to a better understanding of ageing trajectories. Integrated spatial and temporal approaches are utilised, including the analysis of various demographic and developmental factors. Political, geographical and developmental features are also used as these determine the spatial pattern of ageing. This article thus investigates the spatial and temporal 
Spatial pattern of structural ageing in Eastern Croatia

variation of factors affecting the ageing process and its spatiality over time in Croatia.

The interdependence of population-environment interactions is recognised by international research (Abdel-Rahman \& Wang 1995; Antrop 2004) and is because of the development of positive long-term human activities within the society (Higgins \& Savoie 2009). Research exploring the aggregate level is often unable to identify the effects of variability at the lower level of data hierarchy, such as at regional or sub-regional level (Khan 1997). The spatial demographic analysis therefore is better suited to understand more precisely the deep-rooted problems in society. According to Voss (2007: 458), "Until roughly the mid-20th century, virtually all demography in the United States and elsewhere was spatial demography, defined as the formal demographic study of areal aggregates," that is, of demographic attributes aggregated to some level within a geographical hierarchy. In recent years, various authors have applied different modes of spatial analysis in demography. Guilmoto and Rajan (2001), for example, analysed spatial patterns of fertility transition in the Indian districts, using kriging (Gaussian process regression) and spatial autocorrelation, whereas others, such as Chi and Ventura (2011), utilised an integrated spatial approach to analyse population change and its driving factors in rural, suburban and urban areas of Wisconsin.

Another important issue covered by this article is the utilisation of time and space combined together in ageing research. This approach has a long history of application that is particularly evident in ageing research conducted by Japanese economic geographers during the 1980s. In order to understand the ageing situation in Japan in relation to international perspectives, Takayama (1983) classified Japanese prefectures by the different spatial patterns of ageing. Extending the same research discourse, Kaneyasu (1987) applied Klaassen's method of spatial analysis (Klaasen 1979) to identify inactive areas with the rapid increase of ageing that pose a threat to the socio-economic stability of Japan. In contrast to these approaches, the present research adopts a slightly different framework by drawing on population dynamics that are essentially temporal and on population geography with its dominant spatial approach. By doing so, it is possible to harness the strong points of both disciplines and offer different insights into population processes. 
In addition to adopting the perspective provided by the spatial pattern of ageing, in this research we also use a notion of structural ageing. This means moving from the typical notion of "ageing population" that has been most commonly used in Croatian demography in the past decades of the 20th century, to a more useful notion of the age-structural shift. According to Harper (2011), an age-structural change perspective allows for viewing population change in terms of a shift between providers and dependents that is particularly important for understanding the economic impacts of an ageing society.

Before giving a detailed ageing analysis of the selected area of eastern Croatia, a brief overview is provided of the dominant population processes in Croatia as a whole. It is followed by an analysis of the relevant ageing indicators shown at the spatial level and the discussion where we suggest the main causes (factors) of the evolution of the spatial pattern of ageing. The article concludes by discussing policy implications and recommendation for future research.

\section{Setting and Historical Context}

Since the mid-20th century, Croatia has been undergoing a deep socioeconomic transformation (Jukic \& Turk 2010). The main driving forces behind the rapid shifts were agricultural restructuring and industrialisation of the urban centres (Jukic 2007, 2011). Deagrarianisation freed a large number of workers in this traditionally agricultural area and has contributed to the growth and rapid expansion of a few urban centres, particularly the development of manufacturing industries and services. Friganovic (1987) says that these processes have been accompanied with a decline for fertility, out-migration and depopulation across large tracts of peripheral rural areas. All this has caused profound changes in demographic trends and has consequently generated a spatially different pattern of ageing (European Commission 2011; UN 2012). The economic and social significance of this change and its implications are yet to be fully appreciated. So far, researchers have posited strong links between general underdevelopment as well as the factors of peripheral geographic location, weaker employment opportunities, unadjusted settlement network, poor access to health care and education, inadequate availability of transportation and dissatisfaction with quality of life (Jukic 2011). 
Osijek-Baranja is a geographical region of eastern Croatia, administratively referred to as Osijek-Baranja County. ${ }^{1}$ It is a prime example of spatial unit experiencing demographic, socio-economic and developmental decline that has proved to be much deeper and more pronounced when compared with other parts of Croatia. For the sake of simplicity and consistency, this region will be referred to in this article as "Osijek-Baranja."

There has been no research carried out in Croatia until now for identifying the aspects of spatial distribution of ageing and their evolution. Such a study is urgently needed in order to provide guidelines for local and regional planning. As pointed out earlier, research efforts have been made but only using macro data, particularly at the state level, which does not provide deeper insights into the evolution and consequences of factors affecting the population. It is only recently that Croatian authors have applied slightly different approaches to their explorations of the population at the local level. For instance, while analysing the determinants of fertility and mortality, Jukic and Turk (2010) discovered and explained significant micro-level variation within Osijek-Baranja. The glaring discrepancies, as noted by the authors, had an unfavourable effect on development at the local level. A hint of similar findings can be seen in the results of a social survey of rural households in Dakovo area that is located in the southwestern part of Osijek-Baranja (Jukic 2007).

\section{Methodology}

The analysis is drawn from two major data sources: (1) decennial population censuses of Croatia (1961-2011) and (2) yearly vital statistics (see data). There are strong reasons to believe that this period is of the highest importance in determining the evolution of, and providing an explanation thereof, the spatial pattern of structural ageing. The censuses conducted during the four decades of the 20th century make it possible to capture the effects of all the dominant factors behind the emergence of spatial discrepancies in indicators of ageing. The analysis stretches to the Census of 2011 as we believe that the years between 1991 and 2001, during which

\footnotetext{
${ }^{1}$ In spatial terms, Osijek-Baranja corresponds to the NUTS3 statistical level of the European Union (Nomenclature of Territorial Units for Statistics), codified as HR04B (CBS 2012).
} 
International Journal of Ageing and Later Life

time there was the war in the Balkans, help to give final shape to the ageing pattern in terms of its spatial structure. The demographic processes in the last available intercensal periods between 2001 and 2011 are characterised by a continuation of negative population trends but without significant changes in the spatial pattern of structural ageing. Therefore, the main analysis here is focused on the earlier periods when a contemporary ageing pattern was formed.

Spatial demographic analysis was made in two ways: the data on ageing was extracted from the censuses/vital statistics and adjusted to spatial units having in mind all the changes in territorial organisation over the period 1961-2011. The interpretation of causes and consequences of changes in the spatial pattern of ageing builds upon detailed empirical analysis of several factors in the same area and period: historical and industrial development, labour supply, urbanisation, agricultural restructuring and the domestic war.

From a methodological point of view, there are some technical constraints in the spatio-temporal analysis provided in this article. This is the case even after statistical and mathematical methods of data analysis have proven to be successful when it comes to their application to spatial analysis (Bailey \& Gatrell 1995; Fotheringham et al. 2000; Haining 1990). A spatial dataset of 42 municipalities (with 265 settlements) of the time-constant area of OsijekBaranja has also been used to examine how factors are associated with these units and how they shaped the spatial pattern of structural ageing from 1961 to 2011. Such analysis allows us to capture variation at the sub-regional level of the county. The advantage of using municipalities, as a unit of analysis, is their relevance to planning as each unit has a solid level of autonomy in raising revenues and provision of services to their population. Municipality boundaries have been changed in the past, but the data were adjusted in accordance with the latest administrative divisions to assure spatial consistency over time. To provide a stronger background to the evolution of the spatial pattern of ageing, the analysis is supported by the examination of ageing indicators for urban and rural settlements, as well as for six subregions (areas). These sub-regions are, in fact, groups of rural settlements administratively and functionally oriented to a particular urban centre.

We define ageing population as those aged 65 years and over with ageing index and dependency ratios used to compare ageing situations 
Spatial pattern of structural ageing in Eastern Croatia

over the period 1961-2011. The ageing index is defined as a ratio between the population aged over 65 and under 15 years of age. The spatial level analysis ranges from lower to higher levels - from local level (urban and rural settlements), the medium level (municipalities and sub-regions), to regional level (county) - thus capturing an overview of ageing trajectories and variation at the different levels.

\section{Data}

There are at least two major problems with all censuses conducted in Croatia (especially between 1961 and 1991): (1) relatively low level of detail and (2) lack of consistency and comparability in socio-economic variables. The disadvantages are especially exposed when it comes to migration. Croatia does not have well-defined migration statistics (neither in the form of Census or Population Register). The only way to infer about whether some area (spatial unit) has immigration or emigration is by measuring a net migration balance (comparing total population change with the vital statistics). The census data contain age, sex, education, economic activity, primary occupation (main types of job) and ethnicity, but not all of these variables were directly used in this research.

\section{Results and Discussion}

\section{Croatian Demographic Transition}

In order to understand the evolution of the spatial pattern of structural ageing in eastern Croatia, it is necessary to provide a brief overview of the characteristics of the Croatian demographic transition. Since the end of the Second World War, which was immediately followed by a short "baby boom" period, Croatia has experienced a continuous fertility decline. This decline lasted up to the beginning of the 21st century when fertility levels stabilised at the level of below replacement. The total fertility rate (TFR) has gradually declined since the 1960s, falling sharply from 2.30 in 1961 to 1.99 in 1981. It reached the lowest level of 1.38 by 2001, and according to the 2011 census, has slightly increased again to 1.46 (CBS 2013). This means that during the 1980s, with a much lower level of economic development, 
International Journal of Ageing and Later Life

Croatia had a TFR similar to developed European countries. As Sobotka (2011) pointed out, the lowest recorded fertility level at the turn of the century is consistent with fertility trends in other Central and Eastern European countries after the collapse of communism. Mortality in the last half of the 20th century, on the contrary, was already low and similar to other European countries (Svaljek 2011) and so has not played an important role in the demographic development of the country. The life expectancy at birth in Croatia has gradually risen from 66.4 (68.9 Female; 64.0 Male) in 1961 to 76.1 years (80.3 Female; 73.6 Male) in 2011. During the same time period, Osijek-Baranja showed a similar trend of fertility decline but at a significantly lower level of TFR: 1.70, 1.55, 1.16 and 1.20 in 1961, 1971, 2001 and 2011, respectively.

Migration is an important factor that altered demographic development of the Croatian population in the second half of the 20th century because of unprecedented out-migration. Between 1961 and 1971, the net migration balance has been negative by over a quarter of a million $(-258,469)$. This position recovered slightly during the 1970s $(+58,689)$ and 1980s $(+33,407)$ and then rapidly dropped in the period between 1991 and $2001(-247,355)$. In the last 10 years for which data are available (2001-2011), the net migration balance is estimated to be around $-146,000$. In the earlier research, Jukic (2011) demonstrated that since the 1960s, Osijek-Baranja has experienced a net loss of young people moving mainly to other European countries. It is important to acknowledge that the investigated area belongs geographically to eastern Croatia where the domestic war of the early 1990s additionally accelerated out-migration. In the 1990s, the crude rate of net migration in Osijek-Baranja went down to $-35,518$ (nearly $10 \%$ of the total population). There is evidence to suggest that those who emigrated were generally of a younger age and higher level of education (Jukic 2011; Jukic \& Turk 2010; Turk \& Jukic 2010).

In a nutshell, between 1991 and 2011, fertility decline and out-migration both contributed to an overall decline in the size of the Croatian population. At the same time, the ageing has progressed because of a continuous decrease in the numbers of the youngest cohorts (0-14) and a fairly rapid increase in the numbers of the elderly $(65+)$. A future population decline is expected. According to the ageing index, in 2012 Croatia held ninth place in Europe (120), with only Germany (157), Italy (150), Bulgaria (141), 
Spatial pattern of structural ageing in Eastern Croatia

Greece (136), Latvia (130), Portugal (129), Austria (124) and Lithuania (123) being ahead (European Commission 2011). A majority of these countries belong to Southern Europe or to a post-communist Central and Eastern Europe that witnessed a significant decrease in fertility rates. The latter group of countries, including Croatia, experienced a shift from communism to capitalism that included drastic socio-economic changes accompanied by deteriorating living standards, employment uncertainty and a rise in income inequality (Frejka 2008; Kohler et al. 2002; Sobotka 2011).

\section{Population Ageing in Osijek-Baranja}

Demographic processes identified at the national level also apply to Osijek-Baranja in the same period. The share of younger population (under 15) has declined from 29.1\% (1961) to 15.3\% (2011). During the same period, the elderly population has significantly increased from $6.4 \%$ to $16.9 \%$, and the ageing index has increased by almost five times, from 22.0 to 110.1. In comparison with the national data, Osijek-Baranja had only a slightly younger population (CBS 2012, 2013).

Previous studies by Jukic and Turk (2010) and Jukic (2007) proved the interdependency between ageing and urbanisation. As the strongest centre for urban-based industrialisation and the central hub for political and territorial organisation, Osijek provided the highest supply of jobs in the manufacturing industry, as well as jobs in services and administrative affairs, while all other urban settlements had only a limited effect. The functional weaknesses of certain urban centres (limited supply of jobs) prompted workforce to emigrate to surrounding rural settlements. In 1961, both urban and rural settlements had a fairly balanced ageing index, with only a slightly higher level in rural (22.2) compared with urban settlements (21.8). The figures have drastically changed within two decades. In 1981, there was an increase of 51.4 and 39.8 in rural and urban settlements, respectively. This substantial difference was mainly a consequence of an intensive rural-to-urban migration that reached a peak during the 1960s and 1970s. By 2001, the difference had disappeared and the data for 2011 show that rural settlements had lower ageing index (101.1) than urban (121.1). The urban immigrants of the 1960s and 1970s mostly entered into old age, while the out-migration of young urban people increased during the 1990s. The differences between particular urban centres and within different rural 
International Journal of Ageing and Later Life

areas in this locality were very pronounced throughout the entire recorded period. This finding requires further analysis at lower levels.

Within the study period, all urban centres experienced an increase in the ageing index (Figure 1). In 1961, its values were fairly balanced, with slightly higher levels in the peripheral urban centres near the CroatianHungarian border, namely Donji Miholjac and Valpovo. Although the ageing index increased over the next 30 years in all centres, the growth was steady. However, after the 1990s, the value rapidly increased. According to Jukic (2011), such an increase was partially prompted by the selective outmigration of the younger population as a consequence of war. But one of the main reasons behind it was ageing of the immigrant cohorts that had moved to the cities in the 1960s and 1970s. The 2011 Census data show that of those cities highly exposed to war activities in the 1990s, Osijek and Beli Manastir (occupied by Serbian forces from 1991 to 1997) had the highest ageing index. The most striking feature is the ageing index of Osijek that reached 135 (old population exceeding young by 35\%). Such advanced ageing in the regional capital that makes up one-third of the total

Figure 1. Ageing index of the urban settlements in the period 1961-2001. Source: CBS (2013).

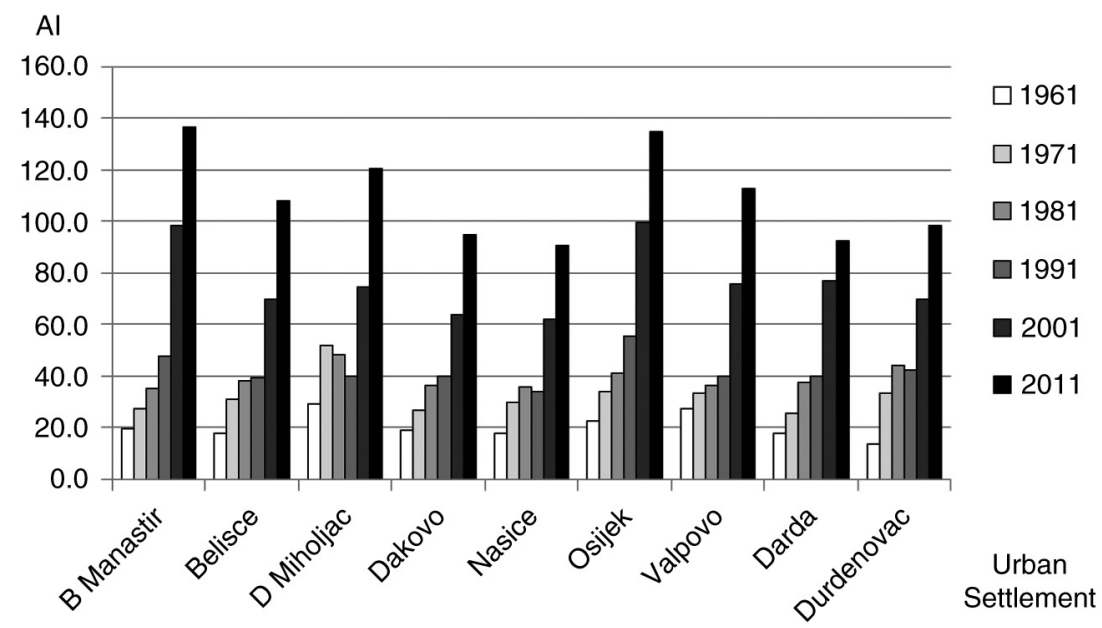


population, heavily weighted the overall ageing of Osijek-Baranja. By contrast, Nasice, Dakovo and Darda maintained the lowest values of ageing index in 2011. Moreover, Dakovo was the only urban settlement where the total population increased in the post-war period (1991-2001), while Nasice experienced the lowest decrease of total population.

A comparison of the ageing indices among six sub-regions of rural settlements is given in Figure 2. It is evident that the ageing process has progressed significantly over time with noticeable local differences. However, huge disparities can be seen between Baranja and especially Miholjac sub-regions on one hand, where both stood out as the "oldest" areas, and Dakovo and Osijek on the other, representing the areas with the youngest population. It is generally well documented that within the population of the first two sub-regions, fertility decline and emigration started earlier compared with the other two sub-regions (Jukic \& Turk 2010).

Figure 2. Ageing index in the rural settlements of the six sub-regions of Osijek-Baranja County in the period 1961-2001.

Source: CBS (2013).

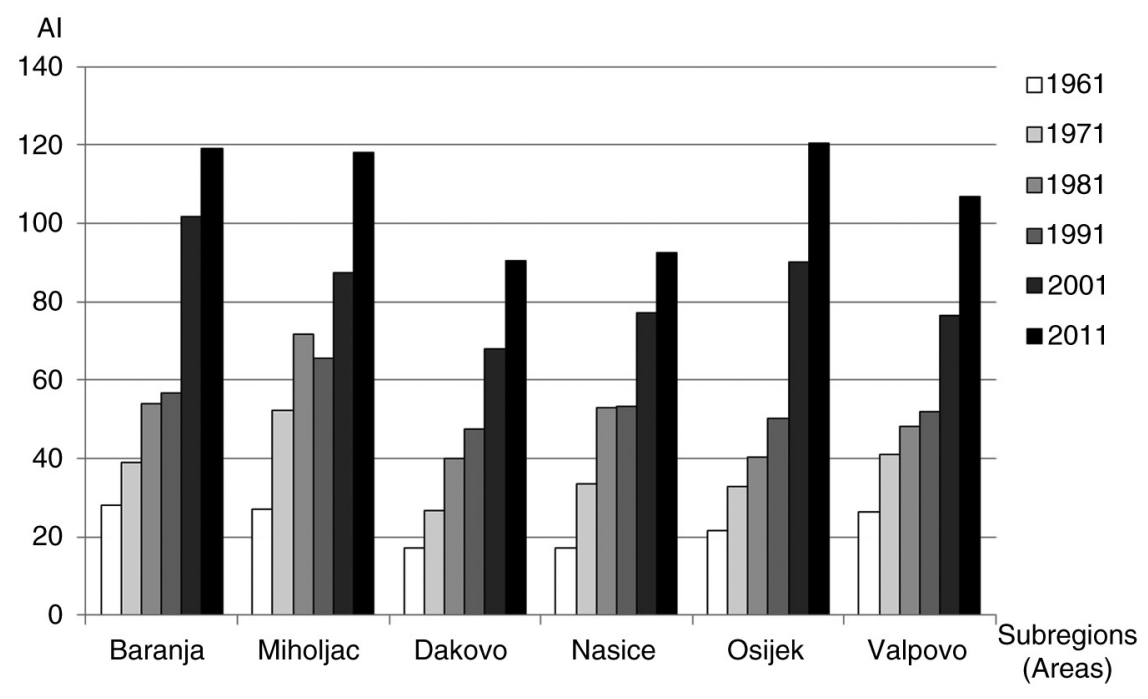


International Journal of Ageing and Later Life

\section{Ageing at the Municipality Level}

The ageing index at municipality level reveals a spatial dimension of ageing. This helps in understanding the influence of certain factors that caused spatial disparities in the ageing pattern. To examine their effect, we first consider the period 1961-1981. Figures 3 and 4 show the direction and intensity of changes in these decades. In 1961, when the dominant socioeconomic processes just started to shape development and consequently the population, the ageing index did not differ considerably across the county. The peripheral eastern and northwestern areas had a slightly higher value,

Figure 3. Ageing index of the municipalities in 1961.

Source: CBS (1962).

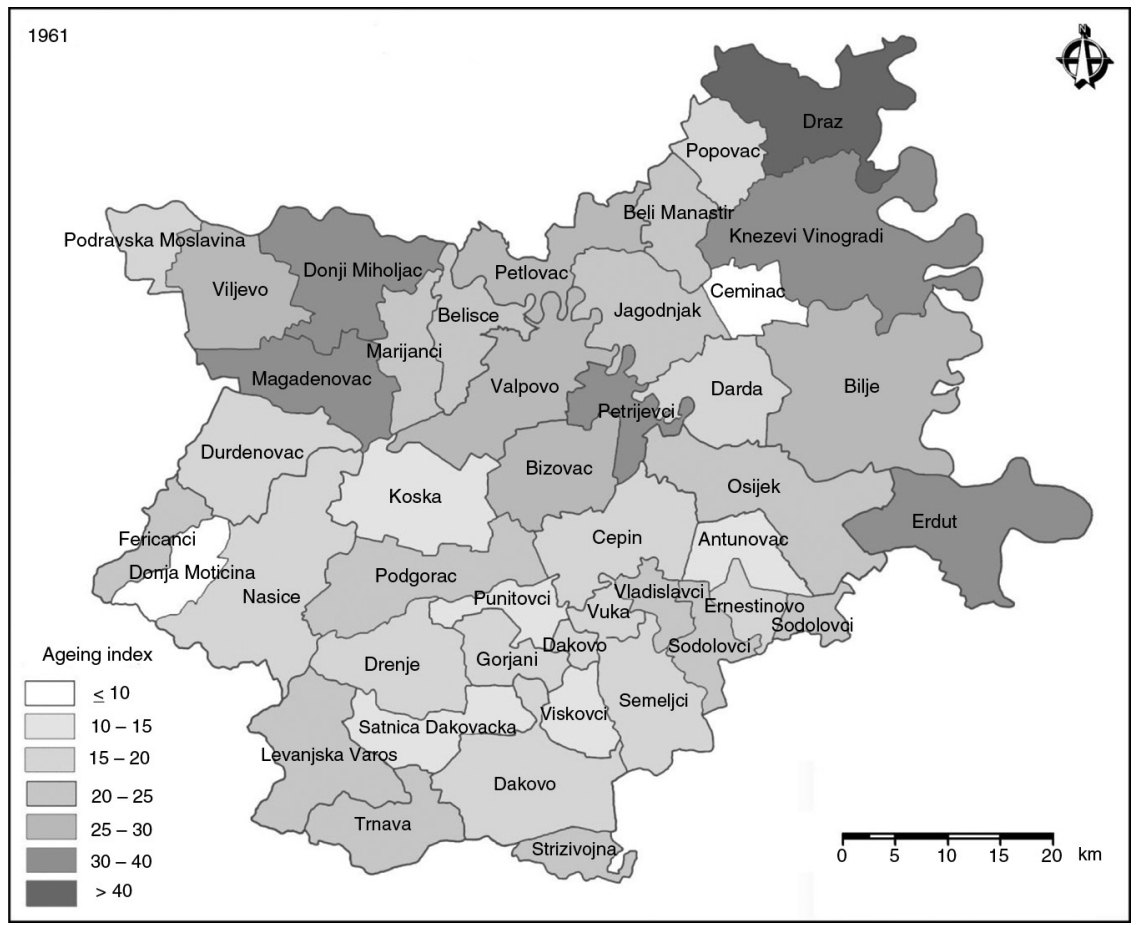


Figure 4. Ageing index of the municipalities in 1981. Source: CBS (1981).

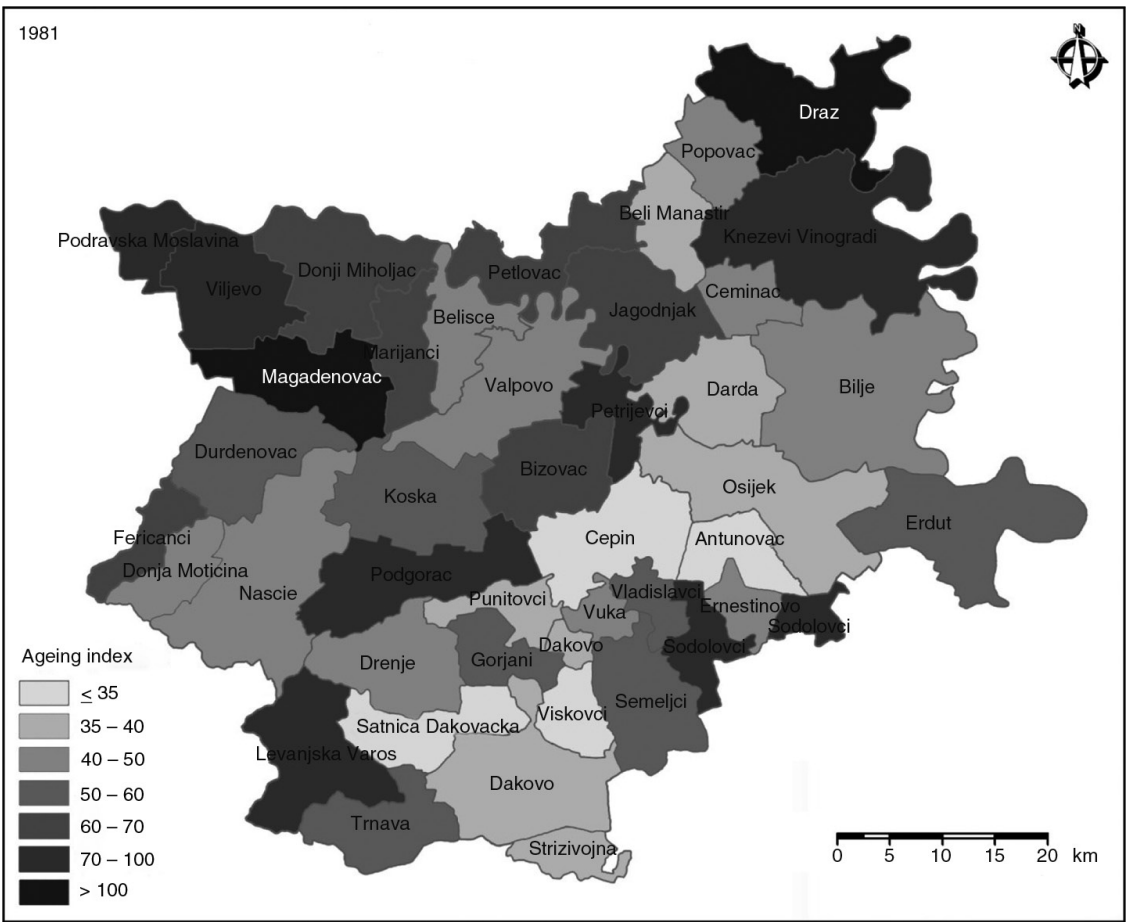

somewhere between 30 and 40 . These parts, especially the rural settlements of Draz municipality (66.8), were already sparsely populated, mostly because of the bordering position and isolation from main traffic thoroughfares. By contrast, the southern areas, especially the settlements of the Dakovo area and the southern part of the Osijek area, had a very low ageing index. Before the Second World War, as these areas were rich in fertile soil, they had been a destination point for the immigration of farmers from other parts of Croatia and surrounding countries, especially from Bosnia and Herzegovina (Jukic 2007). Consequently, larger settlements have formed, 
International Journal of Ageing and Later Life

particularly along the main traffic thoroughfares from Osijek to Dakovo, thereby connecting this region with other parts of former Yugoslavia, the state that ceased to exist in 1991.

Figure 4 shows the structural ageing index in 1981. First, ageing index increased drastically across the county, followed by an apparently new pattern of ageing, separating those areas with highly advanced ageing from those areas with a much younger population. The outermost northwestern and eastern areas maintained lead position in the intensity of ageing, but their territorial coverage had been extended by 1981 . These areas covered the rural settlements in all municipalities of the Miholjac area, together with the northern part of the Nasice area and almost the entire Baranja area, with the exception of municipalities along the main route that runs from Beli Manastir to Osijek. The western hilly municipalities of the Dakovo area that once had a very young population experienced higher ageing during the 1960s and 1970s. In some municipalities, such as Levanjska Varos, the ageing index doubled during this period.

In contrast, the lowest value in 1981 was recorded in the area stretching northeast to southwest, covering the regional capital of Osijek, its suburban area and the eastern part of the Dakovo area. The reason was not only a better connectivity because of the favourable position on or near the main traffic route that also enabled the establishment of a commuting system for the workforce but also traditionally higher fertility rates that have historically been recorded in the eastern Dakovo area. Wertheimer-Baletic (1995) argues that the higher fertility rate identified throughout the 20th century in the Dakovo area has been a consequence of constant population replacement affected by the migration of farmers. According to this author, while the autochthonous population was leaving, population from other parts of Croatia that were characterised by infertile soil and the high density of the farming population per unit of farming land was immigrating. It is important to note that the eastern parts of the Dakovo area boast the most fertile soil in Croatia (OSPO 2001).

The evolution of the ageing pattern between 1961 and 1981 has apparently been driven by planned industrialisation that took place mainly in the regional capital of Osijek and, to some extent, in smaller urban centres. Together with agricultural changes in the wider region, this process has triggered migration and helped to shape its patterns. Young people 
(potential parents) were primarily pulled out of rural areas and directed towards the urban centres, where they found jobs in industry and services. The areas within the reach of urban centres have developed commuting systems for use by their labour force that helped prevent a complete loss of their inhabitants of working age. This can be seen most obviously in Osijek's surrounding areas and the settlements along the main traffic routes connecting the capital with Dakovo, Belisce and Beli Manastir. In the case of other urban centres, political and territorial organisations have contributed significantly by acting as a complementary force to planned industrialisation and by enabling the rise of services. Old municipalities (prior to 1991) were organised around six centres and had complete autonomy in deciding about the future planning of their economies (Zuljic 1982). Planned industrialisation acted as an anchor that prevented the total loss of the younger labour force, released by the agricultural restructuring of adjacent rural areas. However, the reach of their influence was constrained by their weaker economic power and by the lack of quality traffic connections (road and rail).

Rural areas situated away from this "growth axis" were exposed to rapid "ageing in place." The birth rate was already very low and the sex ratio imbalance fuelled its decline further. The men usually stayed on their agricultural properties, while women emigrated in larger proportions to find jobs in the cities. This process is in accordance with the general theory of village communities by Mendras (1976) who claimed that women started to emigrate from rural areas at a later stage than men, but when women joined the process, it was in very large numbers. In Osijek-Baranja, this same process occurred during the 1960s and 1970s. An indication of a further fertility decline in rural areas emerged because of an imbalance in the cohorts ranging from 15 to 34 years old. The sex ratio here oscillated around 90 females to 100 males in 1981, while in some areas, such as the municipalities of the far northwest and northeast, it reached 75 females to 100 males.

The period between 1991 and 2011 represents a final stage in the development of ageing pattern in Osijek-Baranja (Figures 5 and 6). A comparison of the two ageing patterns reveals an apparent advancing of the process across the county but with significant differences in its intensity. The municipalities with the highest increase of the ageing index are those directly exposed to war in the 1990s. The ageing index in 2011 reached its 
Figure 5. Ageing index of the municipalities in 1991 (pre-war state). Source: CBS (1991).

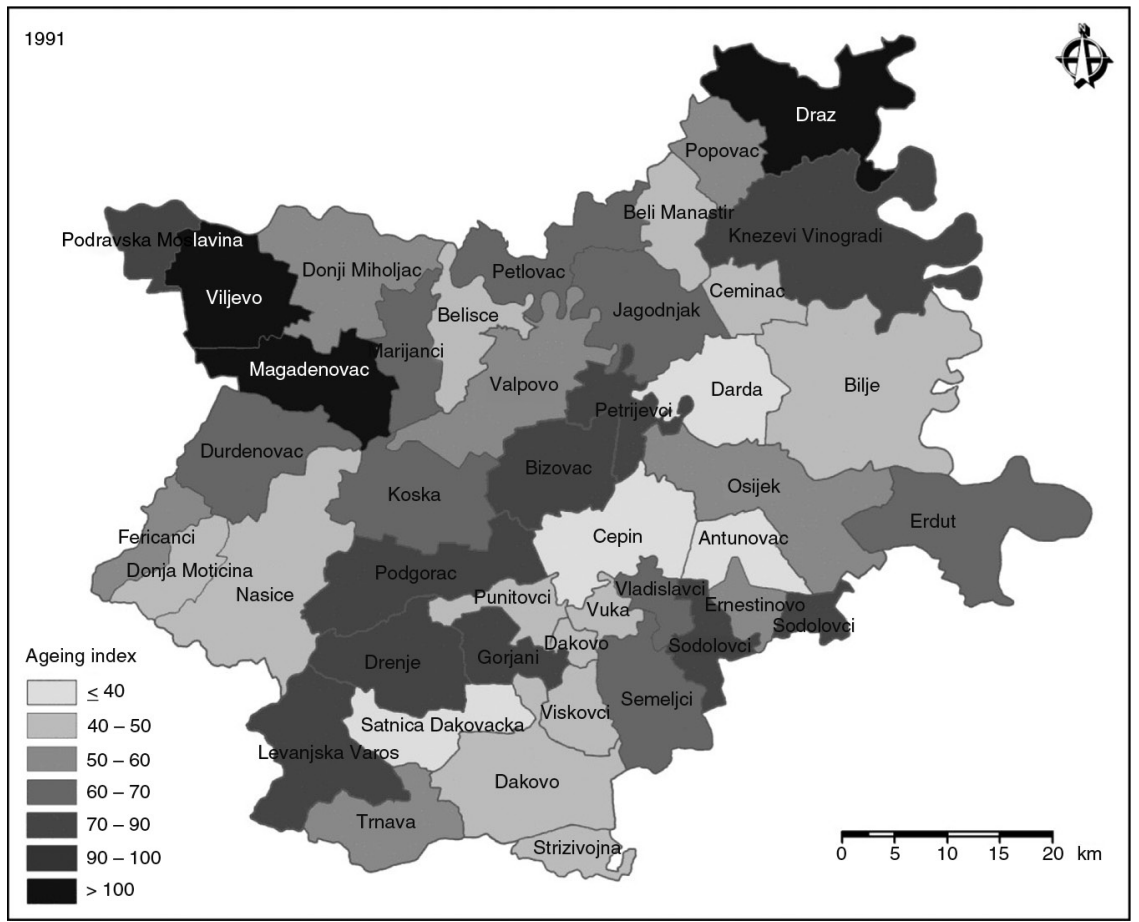

maximal values in the municipalities of Baranja and the peripheral parts of the Osijek area. The domestic war had a crucial impact on the advancement of ageing in these areas, but to completely support this argument, we must bear in mind three important facts: (1) Baranja and the peripheral parts of the Osijek area were an ethnic mixture dominated by Croats but with significant numbers of Serbs; (2) because of the economic collapse during the occupation period (1991-1997) and after, the Serbs have mainly emigrated to Serbia; and (3) because of the scale of economic devastation, younger generations of Croats decided not to move back to these areas. It is 
Figure 6. Ageing index of the municipalities in 2011 (post-war state). Source: CBS (2013).

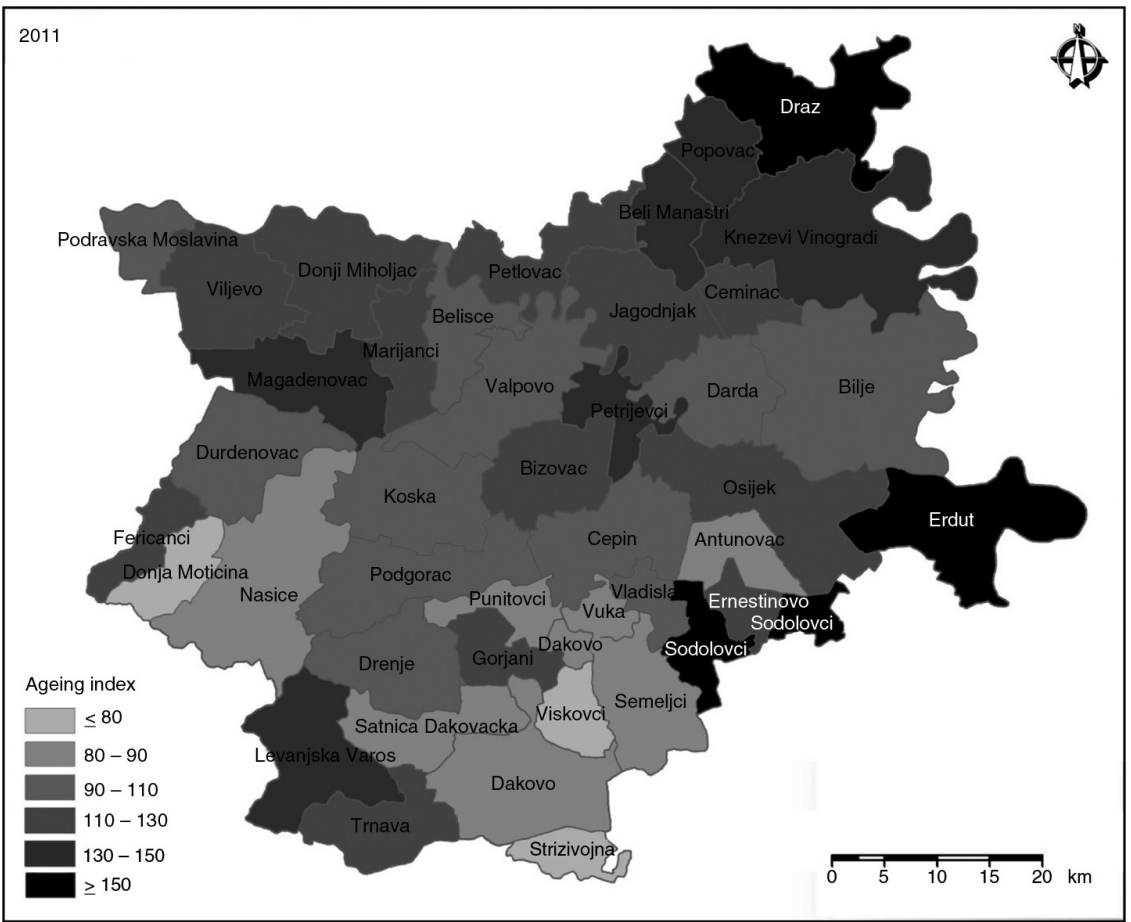

also noteworthy that the war was not the only reason for the degraded economy of the region (Jukic 2011). An area of continuously highly advanced ageing, where the effects of war were not so profound, stretches from the northwestern Miholjac area, through the middle of the Nasice area to the western hilly parts of the Dakovo area. The advancement of ageing in these areas is a consequence of the insufficiencies from previous periods, particularly the absence and/or underdevelopment of surrounding urban centres, that triggered the emigration of younger people and ageing in place of older residents. 
International Journal of Ageing and Later Life

The areas with more favourable ageing levels, expressed through the ageing index, were spatially reduced from 1991 to 2011 (Figure 6) to include small tracts of the southern Osijek area and the eastern part of Dakovo area.

\section{Synthesis of Spatial Differences}

An advantage of the spatial approach in demography is its ability to allow for visualisation and thereby provide explanations from cartographic representations. It is perhaps a powerful tool to identify and tease out the effects of important variables. The evolution of the ageing pattern perceived through the change of the ageing index at municipality level between 1961 and 2011 (Figures 3-6) enables us to make a clear distinction between the areas that ended up in completely different phases of structural ageing in 2011. That particular moment reflects the influence of the main driving factors affecting the change in the ageing pattern and is found to be different from all the previous periods. Given all the above, five areas can be identified showing those with the most adverse characteristics of ageing up to those having the most positive features:

1. Almost the entire Baranja area (excluding Osijek suburban area of daily commuting), together with the peripheral eastern part of the Osijek area (Erdut and Sodolovci), is characterised by very advanced ageing (i.e. the ageing index is higher than 130). The share of older people in many settlements goes well beyond $30 \%$, and some villages have completely lost their population (e.g. Podunavlje, Sokolovac and Suduraz). Ageing in those areas is the consequence of an immersive interaction between poor connectivity (lack of proper roads), proximity of the border (economic underdevelopment of the trans-border area of Serbia and Hungary) and poor supply of labour. These factors laid the foundations, but the war in the 1990s struck a vital blow that accelerated ageing. We should reiterate that the Serbs occupied these areas for 7 years, up to 1997, when peaceful reintegration took place.

2. A continuous area stretching from the hilly municipalities of the western Dakovo area to the lowlands of Miholjac, where ageing is highly advanced (i.e. the ageing index in excess of 110). A share of the elderly in many settlements is higher than in the foregoing area 
Spatial pattern of structural ageing in Eastern Croatia

(often around 50\%), which is mainly a consequence of the smaller settlement sizes (some have less than 50). However, a substantive difference between this and the area described in (1) above is that it more or less reached a highly advanced "stage of ageing" long before the 1990s, with some areas doing so in the 1980s. In this area, the war did not have a significant influence. The most important reasons for ageing here was its remoteness from the main traffic corridor and a delay in setting up industrial facilities. It is also because of insufficient diversification of the economy in Nasice and Donji Miholjac, the cities that should have served as a destination for the workforce "released" from agriculture in the years between the 1960s and 1980s. They industrialised during the 1980 s, far too late to retain the population in the more distant settlements of their sub-regions.

3. Spatially limited and discontinuous zones around five urban settlements of secondary importance (Nasice, Valpovo, Belisce, Beli Manastir and Donji Miholjac) characterised by a relatively better ratio between the old and young populations, especially when compared with the areas mentioned in (1) and (2) above. The ageing index in these zones increased steadily between 1961 and 2011, reaching its peak in 2011, with the values lying between 60 and 75 . These areas are prime examples of the influence of territorial and administrative organisation on socio-economic conditions that had an effect on ageing. Limited industrialisation was mostly carried out in the 1980s while administrative rules adopted by these former centres of municipalities attracted younger people that helped to slow down ageing. The share of the elderly is relatively low, varying around $15 \%$, but it is very likely that it will grow in the future.

4. The regional capital Osijek, which up to 1981 had maintained a relatively young population due to the immigration of working population contingents that arrived during the 1960s and 1970s triggered by an unprecedented growth of industry and services. However, an industrial crisis in the 1980s and the domestic war in the 1990s gave a boost to ageing that resulted in a very high ageing index in 2011 (135). The advancement of ageing in the past few decades is a combination of ageing in place, particularly among the immigrants of earlier periods, and enormous out-migration as a consequence of the war. It is 
International Journal of Ageing and Later Life

noteworthy that Osijek lost nearly $20 \%$ of its population in the years from 1991 to 2011, with emigration largely comprising younger (working age) Serbs while older Serbs stayed in the city (Turk \& Jukic 2010). The emigration of Croats continued between 1991 and 2011, primarily as a consequence of the breakdown of industry and high rates of unemployment.

5. A continuous area of suburban settlements in the southwest of Osijek, including a narrow zone stretching along the main traffic route running from Osijek to Dakovo and further south, as well as the town of Dakovo with its surrounding settlements. This area is characterised by the lowest ageing index in Osijek-Baranja, ranging between 70 and 90, and with a relatively low share of the elderly. According to Jukic (2011), this situation is the result of a recent spatial redistribution of the population within Osijek's urban region. This means that younger people may have moved from the city to these areas, thereby directly decreasing the share of the elderly, and also indirectly through the influence of higher fertility rates. Good connectivity along the main traffic route from Osijek-Dakovo has enabled the workforce to commute daily, which was crucial for the prevention of permanent out-migration. It is noteworthy that the zone of the eastern Dakovo area has been traditionally a high fertility area (Jukic 2007).

An examination of the changes in the elderly dependency ratio (EDR), that is, the ratio of older dependents (65 years or more) to the working-age population (aged 15-64 years), between 1961 and 2011, has shown that the EDR has increased over the years. As Sanderson and Scherbov (2007: 49) underscored, "the old dependency ratio has been used to analyse different aspects of ageing ranging from retirement across the burden of public pensions to the more amorphous concept of old-age dependency itself." However, research on dependency ratios in developed countries, where many people aged 65 and above are living independent and active lives (income coming from a variety of sources, including savings, returns on investments and private and public pensions), cannot be fully applied to Croatia. It is important to keep in mind that the usual retirement age in Croatia is still 65 years for males and 60 years for females, as well as the elderly in Croatia depending on pensions provided by the government. 
Spatial pattern of structural ageing in Eastern Croatia

The majority of the retired population comprises former farmers and their situation is bad as they do not have a full pension funded by the government. The poverty and inaccessibility of goods forces them to keep working on small agricultural properties around their houses. An additional unfavourable factor is that most of them live in the remote and sparsely populated municipalities in the peripheral parts of Osijek-Baranja.

In 1961, before the major socio-economic transformation started, the EDR had been relatively low throughout Osijek-Baranja. Most municipalities had an EDR ranging between 7.5 and 12.5. The exceptions were the municipalities in the far eastern part of Baranja and the northwestern Miholjac where the EDR was much higher (around 20). As mentioned previously, these areas were already sparsely populated in the 1960s because of the long-lasting emigration prompted by their relative isolation from their main traffic routes, bordering position and the lack of work in industry and services. By contrast, the southwestern parts of Osijek area, almost the entire Dakovo area and the central parts of Nasice area had very low EDR (e.g. 6.4 in Osijek). Their age-structure was young because of the very high fertility rates and in some parts, because of the long-lasting immigration from previous periods (particularly the Dakovo area and the suburban area of Osijek city). However, by 2011, the ageing process had changed the EDR dramatically. Its values have increased throughout the county but with a noticeable spatial difference. The area with the lowest EDR covered the suburban area of Osijek city, the eastern Dakovo area and spatially isolated spots around Nasice. On the contrary, the highest EDR was recorded in the Baranja hilly parts west of Dakovo and in the Miholjac area.

\section{Conclusions}

The results presented in this article reveal important insights into the main reasons behind the demographic transition and evolution of the ageing pattern in eastern Croatia. The evidence from Osijek-Baranja indicates a strong correlation between the main socio-economic processes that took place between 1961 and 2011 and the spatio-temporal variation in the ageing pattern. The article also demonstrates the causality that is perhaps interlinked with the changing nature of the ageing pattern and vice versa. 
International Journal of Ageing and Later Life

The scenarios described are changing along with the pace of development and also over time. The population and development interdependence at various spatial levels provide useful insights for regional and local planning.

The ageing pattern, mainly perceived through changes of the ageing index in the period 1961-2011, has shown the advancement of ageing throughout the county, but the differences between "younger" and "older" areas that existed in the 1960s are still apparent. Highly aged population areas spatially increased until 2011 to cover large tracts of the county, including Baranja, Miholjac area, the central Nasice area and the western Dakovo area. They coincide spatially because of their remoteness from main traffic routes, limited job opportunities in their local urban centres and their close proximity to developments in the domestic war. In contrast, the areas of less evident ageing are located along the traffic route between the Osijek and Dakovo areas and correspond with a higher supply of jobs, strong administrative centres, good connectivity and weaker influence of the domestic war.

We suggest that there are at least five main factors that have influenced the evolution of the ageing pattern: (1) traffic connectivity, (2) politicalterritorial organisation, (3) supply of jobs in urban centres, (4) deagrarianisation and (5) domestic war in the 1990s. Previous studies have also shown that the population of the selected area was drawn to the "growth poles" where these factors created favourable conditions. Although a detailed examination of each factor is beyond our research scope, it is crucial to posit some important links between them and ageing. When it comes to the first factor, it is noteworthy that during the socialist period (up to 1991) the county became isolated and inadequately connected with the surrounding and mostly underdeveloped areas of Serbia and Hungary. In such a situation, the traffic route running between Osijek and Dakovo became a lifeline that led to more favourable ageing indicators within its proximity. The second factor, noted previously, preordained the economic basis of the county, as during the years 1961-1991, six urban centres - with Osijek as primary city and five other cities as secondary cities - had almost total autonomy in economic planning. However, the territorial reforms carried out with the foundation of modern Croatia and the newly formed Osijek-Baranja County that included 42 municipalities with Osijek as 
Spatial pattern of structural ageing in Eastern Croatia

the capital, caused smaller cities to lose their importance. The third and fourth factors are parts of an inseparable process that most prominently directed population development and imposed a territorial reconfiguration of the population as a rational necessity. Urban-based industrialisation caused spatial inequalities because of the majority of jobs being located in Osijek and other centres delaying industrial development (Nasice, Beli Manastir) or not attracting a supply of trained manpower. The effects of the domestic war in 1991 and occupation of more than $40 \%$ of the county's territory has not been felt equally in all areas which was reflected in the ageing pattern. A strong migration outflow in the war period was nowhere as evident as in Baranja and Osijek which experienced most of the damage in terms of destruction. As the war-induced migration predominantly included the working-age population and younger generations, who sought jobs elsewhere, the ageing index in these areas in the 1990s increased sharply.

This research has provided a better understanding of the linkages between socio-economic shifts and population ageing in Osijek-Baranja. The problems deeply rooted in society, which are reflected in the spatial pattern of ageing, become visible through spatially detailed and diverse analysis. The importance is even higher because the county is not only underdeveloped compared with other parts of Croatia but has also been harshly torn by war. Ageing has affected economic growth, formal and informal social support systems and the provision of resources for older citizens. Therefore, local and regional planners should use the evidence drawn from the analysis of the ageing index and dependency ratios at various geographical levels to assure the spatially equitable allocation of services for the aged. The municipality level, which was central to this research, is of crucial importance because of its direct applicability to planning. In broader terms, the findings are also valuable for understanding the interactions between population and development, especially in other countries that have undergone a similar transition but from communism to capitalism.

\section{Corresponding Author}

Hafiz T. A. Khan, Department of Criminology and Sociology, School of Law, Middlesex University, London NW4 4BT, UK. Email: h.khan@mdx.ac.uk 
International Journal of Ageing and Later Life

\section{References}

Abdel-Rahman, H. M. \& Wang, P. (1995). Toward a general equilibrium theory of a core periphery system of cities. Regional Science $\mathcal{E}$ Urban Economics 25: 529-546.

Antrop, M. (2004). Landscape change and the urbanization process in Europe. Landscape $\mathcal{E}$ Urban Planning 67: 9-26.

Bailey, T. C. \& Gatrell, A. C. (1995). Interactive Spatial Data Analysis. Harlow: Longman.

Bloomberg (2014). Available on http://www.bloomberg.com/visual-data/ best-and-worst/most-rapidly-aging-countries/ (Accessed: February 1, 2014).

Chi, G. \& Ventura, S. J. (2011). Population change and its driving factors in rural, suburban, and urban areas of Wisconsin, USA, 1970-2000. International Journal of Population Research 2011: 1-14.

CBS (Croatian Bureau of Statistics). (1962). Stanovnistvo prema Spolu $i$ Starosti [Population by Gender and Age]. Zagreb: DZS.

CBS (Croatian Bureau of Statistics). (1981). Stanovnistvo prema Spolu $i$ Starosti [Population by Gender and Age]. Zagreb: DZS.

CBS (Croatian Bureau of Statistics). (1991). Stanovnistvo prema Spolu $i$ Starosti [Population by Gender and Age]. Zagreb: DZS.

CBS (Croatian Bureau of Statistics). (2012). Nacionalna klasifikacija prostornih jedinica za statistiku [National Classification of the Spatial Units for Statistics]. Zagreb: Narodne novine.

CBS (Croatian Bureau of Statistics). (2013). Stanovnistvo prema Spolu $i$ Starosti [Population by Gender and Age]. Zagreb: DZS.

European Commission. (2011). Population Age Structure by Major Age Groups, 1990 and 2010. Luxembourg: European Commission.

Fotheringham, A. S., Brundson, C. \& Charlton, M. (2000). Quantitative Geography: Perspectives on Spatial Data Analysis. London: Sage.

Frejka, T. (2008). Determinants of family formation and childbearing during the societal transition in Central and Eastern Europe. Demographic Research 19(7): 139-170.

Friganovic, M. (1987). Demogeografija: stanovnistvo svijeta [Demogeography: Population of the World]. Zagreb: SK.

Guilmoto, C. Z. \& Rajan, S. I. (2001). Spatial patterns of fertility transition in Indian Districts. Population and Development Review 27(4): 713-738. 
Spatial pattern of structural ageing in Eastern Croatia

Haining, R. (1990). Spatial Data analysis in the Social and Environmental Sciences. Cambridge: Cambridge University Press.

Harper, S. (2011). Demographic transition: Positioning the age-structural change perspective. Population Ageing 4(3): 119-120.

Higgins, B. \& Savoie, D. J. (2009). Regional Development Theories and Their Application. New Brunswick, NJ: Transaction.

Jukic, M. (2007). Utjecaj Demografskih Procesa na Transformaciju Djakovackog Kraja [The influence of demographic processes on the transformation of Djakovstina]. Hrvatski Geografski Glasnik 69(2): 79-98.

Jukic, M. (2011). Demografski Aspekt Prostorne Polarizacije Osjecko-Baranjske Zupanije [Demographic Aspects of Spatial Polarization in Osijek-Baranja Region]. Zagreb: University of Zagreb.

Jukic, M. \& Andrakovic, V. (2009). Dinamika Stanovnistva Grada Osijeka (1857-2001) [The dynamics of the population of the city of Osijek (1857-2001)]. Anali zavoda za znanstveni i umjetnicki rad u Osijeku 25(1): 23-46.

Jukic, M. \& Turk, I. (2010). Dinamicke Demografske Determinante Ruralno-Urbane Polarizacije Osjecko-Baranjske Zupanije [Dynamic demographic determinants of rural-urban polarization of OsijekBaranja County]. Journal of General Social Issues 19(110): 1139-1162.

Kaneyasu, I. (1987). Spatial Pattern of Ageing in Japan. The science reports of the Tohoku University, 7th series (Geography) 37(1): 25-40.

Khan, H. T. A. (1997). A hierarchical model of contraceptive use in urban and rural Bangladesh. Contraception 55(2): 91-96.

Khan, H. T. A. (2014). Factors associated with intergenerational social support among older adults across the world. Ageing International 39: 289-326.

Klaasen, L. (1979). Spatial Systems: A General Introduction (Studies in Spatial Analysis). London: Saxon House.

Kohler, H. P., Billari, F. \& Ortega, J. A. (2002). The emergence of lowest-low fertility in Europe during the 1990s. Population and Development Review 28: 641-680.

McDaniel, S. A. \& Zimmer, Z. (2013). Global Ageing in the Twenty-First Century: Challenges, Opportunities and Implications. Farnham: Ashgate.

Mendras, H. (1976). Peasant Societies: Elements for a Theory of the Peasantry. Paris: Colin. 
International Journal of Ageing and Later Life

Sanderson, W. \& Scherbov, S. (2007). A new perspective on population ageing. Demographic Research 16: 27-58.

Sobotka, T. (2011). Fertility in the history of the 20th century: Trends, theories, policies, discourses. In J. Ehmer, J. Ehrhardt \& M. Kohli (eds.), Historische Sozialforschung [Historical Social Research] (pp. 246-296). Köln: Leibniz.

OSPO (Office for Spatial Planning Osijek). (2001). Prostorni plan OsjeckoBaranjske Zupanije [Spatial Plan of Osijek Baranja County]. Osijek: OSPO.

Svaljek, S. (2011). Demographic ageing and its economic consequences in Croatia. In A. Hoff (ed.), Population Ageing in Central and Eastern Europe: Societal and Policy Implications (pp. 135-150). Farnham: Ashgate.

Takayama, M. (1983). Some considerations on ageing in Osaka metropolitan area. Annals of Economic Geography 29(3): 36-57.

Turk, I. \& Jukic, M. (2010). Changes in the proportion of Croats and Serbs in the ethnic composition of the Croatian Danube region. In D. Zivic (ed.), Mirna reintegracija hrvatskog Podunavlja [Quiet Reintegration of the Croatian Danube Region] (pp. 193-212). Vukovar: Institut Ivo Pilar.

UN. (2012). Life Expectancy at Birth by Sexes. World Population Prospects: The 2012 Revision. New York: United Nations Population Division.

UN. (2013). World Population Ageing 2013. New York: United Nations.

UNFPA. (2012). Ageing in the Twenty-First Century: A Celebration and a Challenge. London: United Nations Population Fund and Help Age International.

Wertheimer-Baletic, A. (1995). Razvoj stanovnistva djakovackog kraja I njegove dinamicke odredbenice [Development of the population of Dakovo area and its dynamic determinants]. Radovi HAZU 33: 91-114.

Wertheimer-Baletic, A. (2004). Depopulacija i starenje - temeljni demografski procesi u Hrvatskoj [Depopulation and Ageing - Crucial Demographic Processes in Croatia]. Journal of General Social Issues 13(4-5): 72-73.

Voss, P. R. (2007). Demography as a spatial social science. Population Research and Policy Review 26(5-6): 457-476.

Zuljic, S. (1982). O ulozi regionalnih centara u rješavanju nedovoljne razvijenosti dijelova SR Hrvatske [On the influence of the regional centres in dealing with underdevelopment of Croatia]. In Z. Baletic (ed.), Nerazvijena podrucja Hrvatske [Underdeveloped regions of Croatia] (pp. 57-70). Zagreb: Economic Institute. 